\title{
E-Commerce Pada Masa Pandemi Covid-19 Berpengaruh Terhadap Peningkatan Volume Penjualan Pada Restoran Gokana Cabang Bintaro Plaza Tangerang Selatan
}

\author{
Kris Dipayanti ${ }^{1}$, Bunga Astra Gracia ${ }^{2}$, Nufzatutsaniah ${ }^{3}$ \\ Universitas Pamulang, dosen01018@unpam.ac.id
}

\begin{abstract}
ABSTRAK. Tujuan dari penelitian ini adalah untuk mengetahui pengaruh E-Commerce terhadap Volume Penjualan. Penelitian ini dilakukan pada Restoran Gokana cabang Bintaro Plaza Tangerang Selatan. Metode penelitian assosiatif digunakan dalam penelitian ini dengan pendekatan kuantitatif. Populasi dalam penelitian ini berjumlah 1000 orang yang merupakan konsumen Restoran Gokana cabang Bintaro Plaza Tangerang Selatan dan jumlah sampel penelitian 91 responden yang ditentukan menggunakan rumus slovin dengan tingkat kesalahan $10 \%$. Penelitian dilakukan dari bulan Februari - April 2021. Pengumpulan data dilakukan melalui observasi dilapangan serta membagikan kuesioner kepada responden. Metode Analisis Data yang digunakan untuk penelitian ini adalah uji validitas, uji reliabilitas, uji koefisien korelasi, uji regresi linier sederhana, uji koefisien determinasi, Uji t dengan mengunakan program SPSS 21. Hasil penelitian menunjukkan adanya pengaruh positif dan signifikan antara e-commerce terhadap volume penjualan dari persamaanregresi $Y=\mathbf{1 8 , 7 2 9}+\mathbf{0 , 5 0 6 X}$. Untuk koefisien korelasi $(R)$ sebesar 0,580 bahwa $e-$ commerce $(\mathrm{X})$ memiliki tingkat kekuatan pengaruh yang sedang terhadap volume penjualan ( $\mathrm{Y}$ ) Dari hasil koefisien determinasi ( $R$ Square) sebesar $33,6 \%$ berarti volume penjualan dipengaruhi $e$ commerce $33,6 \%$ sedangkan sisanya $66,4 \%$ dipengaruhi oleh variabel-variabel lain yang tidak diteliti. Uji hipotesis menunjukkan $t$ hitung $>t$ tabel yaitu sebesar 6,493 $>1,662$, dengan nilai signifikansi $\mathbf{0 , 0 0 0}<\mathbf{0 , 1}$. Artinya $\mathrm{H}_{0}$ ditolak dan $\mathrm{H}_{\mathrm{a}}$ diterima, berarti ada pengaruh yang positif dan signifikan antara e-commerce terhadap volume penjualan
\end{abstract}

Kata kunci : E-Commerce, volume penjualan

ABSTRACT. This research aims to determine the influence of E-Commerce on Sales Volume. This research was conducted at Gokana Restaurant Bintaro Plaza South Tangerang branch. The research used assosiative research method with quantitative approach. The population in this reseach are around 1000 people who are consumers of Gokana Restaurant Bintaro Plaza South Tangerang branch and with Slovin formulas and 10\% error rate, 91 respondents for sample were obtained. The research is from February to April 2021. Collective Data through observation and distribution of questionnaires to the respondents. The analysis data techniques uses validity tests, reliability tests, simple linear regression tests, correlation coefficient tests, coefficient ofdetermination testing, $t$ test with SPSS 21 programme. The results of the study, there is a positive and significant influence, between e-commerce to sales volume by obtaining the regression equation $Y=18,729+0.506 X$. Correlation coefficient value $(R)$ of 0.580 can be concluded that e-commerce $(X)$ has a moderate level of strength of influence on sales volume $(Y)$ and coefficient of determination ( $R$ Square) obtained by $33.6 \%$ means that e-commerce's influence on sales volume while the remaining $66.4 \%$ is influenced by other variables that are not studied. The upper hypothesis test obtained obtained $t$ calculate $>t$ table which is $6,493>1,662$, it is also reinforced by the significance value of $0.000<0.1$. This means that $\mathrm{HO}$ is rejected and $\mathrm{Ha}$ is accepted, meaning there is a positive and significant influence between e-commerce and sales volume.

Keywords: E-Commerce, sales volume. 


\section{PENDAHULUAN}

Ketika pandemi melanda di seluruh dunia, segala aspek bisnis berubah banyak dan perekonomian menurun. Strategi pemasaran produk yang selama ini dipakai tidak bisa lagi diandalkan sehingga harus ada strategi baru untuk memasarkan produk di tengah pandemi. Hal ini terjadi dikarenakan daya beli masyarakat ikut menurun selama pandemi, dimana orang lebih menahan diri dalam membeli sebuah produk. Seorang pebisnis yang pintar harus bisa mengatur strategi pemasaran produk dalam upaya mendapatkan pembeli, mengatur pengeluaran sedemikian rupa, termasuk budget marketing. Dalam kondisi pandemi dibutuhkan sebuah strategi pemasaran produk dengan anggaran minimum dengan memberikan hasil yang maksimum. Terlebih dalam pandemi seperti ini meyebabkan pola konsumsi masyarakat berubah, termasuk dalam hal membeli makanan dimana restoran dan kafe harus membatasi jumlah pengunjung. Banyak orang pun jadi lebih sering masak di rumah. Perubahan seperti ini menjadi tantangan bagi pelaku bisnis kuliner.

Pandemi corona virus disease (covid-19) telah berlangsung di Indonesia sejak awal tahun 2020. Lalu dikuti oleh daerah lain tak terkecuali daerah Tangerang Selatan Banten juga melaksanakan PSBB sesuai dengan aturan pemerintah. Pemerintah Kota (Pemkot) Tangerang Selatan menerapan pembatasan sosial berskala besar (PSBB) Keputusan tersebut berkait dengan permintaan Gubernur Banten Wahidin Halim agar wilayah Tangerang Raya, PSBB dilakukan guna memutus mata rantai penyebaran Covid-19.

Dari pemberlakuan PSBB ini mengakibatkan banyak bisnis yang mengharuskan menutup usahanya lebih cepat dari biasanya dan hanya menerima konsumen setengah dari biasanya karena harus menerapkan pembatasan sosial dengan protokol kesehatan yang ketat, sehingga para pemilik bisnis harus menyiapkan strategi supaya bisa tetap bertahan dan bisa mempengaruhi konsumen dalam melakukan kegiatan pembelian. Karena sebagian besar orang lebih banyak menghabiskan waktu di rumah, penggunaan internet dan media sosial pun meningkat. Pebisnis khususnya pelaku kuliner dapat memanfaatkan media sosial sebagai saluran komunikasi dan penjualan utamanya. Media sosial memungkinkan bisnis untuk menjangkau konsumen yang lebih luas sekaligus membangun kepercayaan mereka.

Dalam usaha makanan, foto atau tampilan visual yang menarik merupakan salah satu kunci untuk meningkatkan interest target konsumen. Maka itu, buatlah konten yang menarik dan relevan dengan target pasar bisnismu agar bisnismu semakin dikenal. Adanya pandemi Covid-19 memaksa pemilik resto atau pebisnis kuliner untuk berpikir kembali dalam menjual produknya. Adanya himbauan untuk tidak melayani makan ditempat, tentunya mempengaruhi sistem bisnis yang biasa dilakukannya. Resto yang semula memfasilitasi konsumen untuk makan langsung di tempat kini harus beralih pada layanan take away atau menjual produk frozen food. Adanya perubahan sistem penjualan tentunya akan berpengaruh kepada sistem lainya seperti sistem produksi, pemasaran, dan distribusi. Dari sistem produksi sendiri ada beberapa hal penting yang perlu diperhatikan seperti jaminan rasa dan ketahanan dari produk yang perlu dipikirkan secara detail, agar ketika sampai kepada konsumen tidak mengurangi kualitas rasa dari produk tersebut. Kemudian dari sisi pemasaran tentunya harus bisa mengoptimalkan pemanfaatan sosial media, ecommerce atau marketplace sehingga memudahkan untuk menjangkau konsumen. Tidak hanya itu keamanan distribusi perlu diperhatikan, penting untuk memastikan produk sampai pada tangan konsumen dalam keadaan yang baik.

PT. Champ Resto Indonesia adalah perusahaan yang bergerak di industri restoran dimana total outlet saat ini mencapai 276 outlet dan akan terus bertambah. Adapun untuk Brand PT Champ Resto Indonesia yaitu : BMK (Baso Malang Karapitan), Platinum Resto, Kopilatinum, Gokana Ramen \& Teppan, Gokana Ramen Bar, Raa Cha Suki \& Barbeque, 
Chopstix dan Bamiko (Baso Mie Kopi). Waralaba Gokana Teppan merupakan restoran yang menyajikan masakan Jepang yang halal dan memiliki citarasa yang sesuai dengan selera orang Indonesia. Gokana memiliki arti 'mewah' dalam bahasa Jepang, dan menghadirkan konsep bernuansa Jepang dengan interior yang mewah. Menu yang disajikan oleh Gokana Teppan merupakan makanan dari jepang seperti tempura, udon dan lainnya. Citarasa yang diberikan oleh Waralaba Gokana Teppan sudah disesuaikan dengan lidah dan gaya Indonesia. Harga yang murah, varian menu yang banyak, bersertifikat HALAL serta porsi yang banyak menjadi kunci sukses Waralaba Gokana Salah satu hidangan paling populer di Gokana adalah teppan yang disajikan di atas hotplate yang mendesis. Menu tersedia dalam ala carte atau 1 set menu. Menu Gokana terdiri dari 6 jenis yaitu Beef Yakiniku Teppan, Bento, Yakimeshi, Ramen, Donburi, Fry Mix dan berbagai macam minuman.

Keadaan yang terjadi saat ini membuat restoran Gokana mau tidak mau mengupgrade kemampuan terhadap dunia digital. $\mathrm{S}$ isi positif dari adanya transformasi bisnis ini adalah, perusahaan memiliki strategi dan sistem bisnis yang baru sehingga dapat tetap beroperasi selama Pandemi Covid-19. Selain itu adanya transformasi dari offline ke online juga berpengaruh terhadap kesuksesan perusahaan di era teknologi saat ini dan masa mendatang. Hal inilah dimanfaatkan untuk restoran Gokana terutama di Cabang Bintaro Plaza, agar bisnis tetap berjalan maka restoran harus lebih banyak memberikan promosi untuk tetap mempertahankan eksistensinya di mata konsumen.

Berikut ini adalah contoh dari promosi yang dilakukan oleh Restoran Gokana di Bintaro Plaza yaitu :

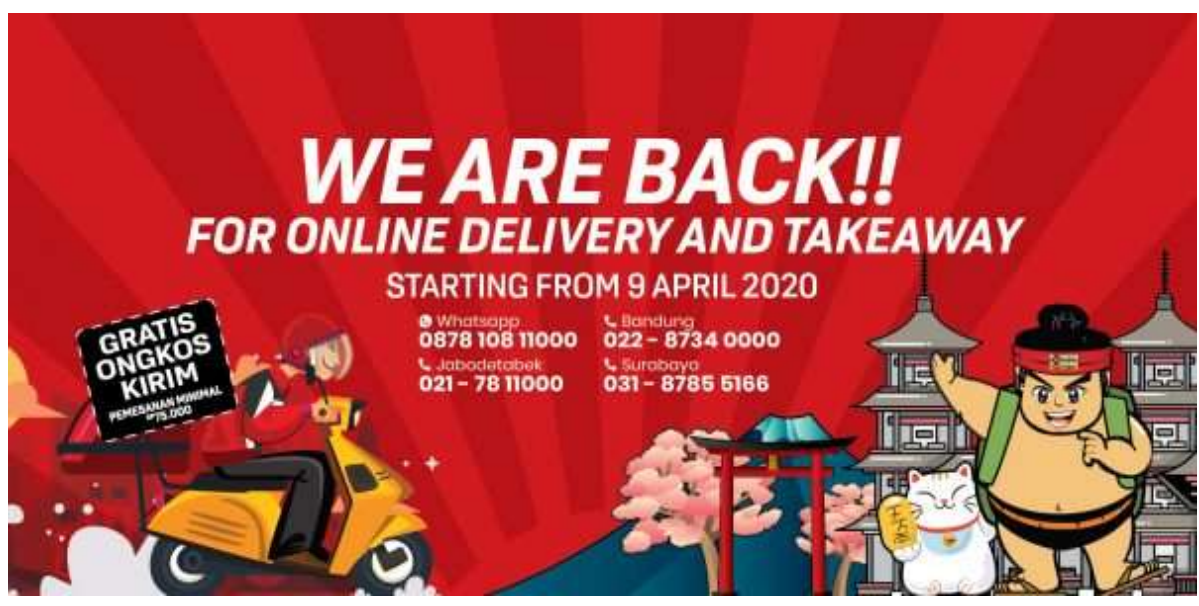

Gambar 1 Promosi Gratis Ongkos kirim pada bulan April

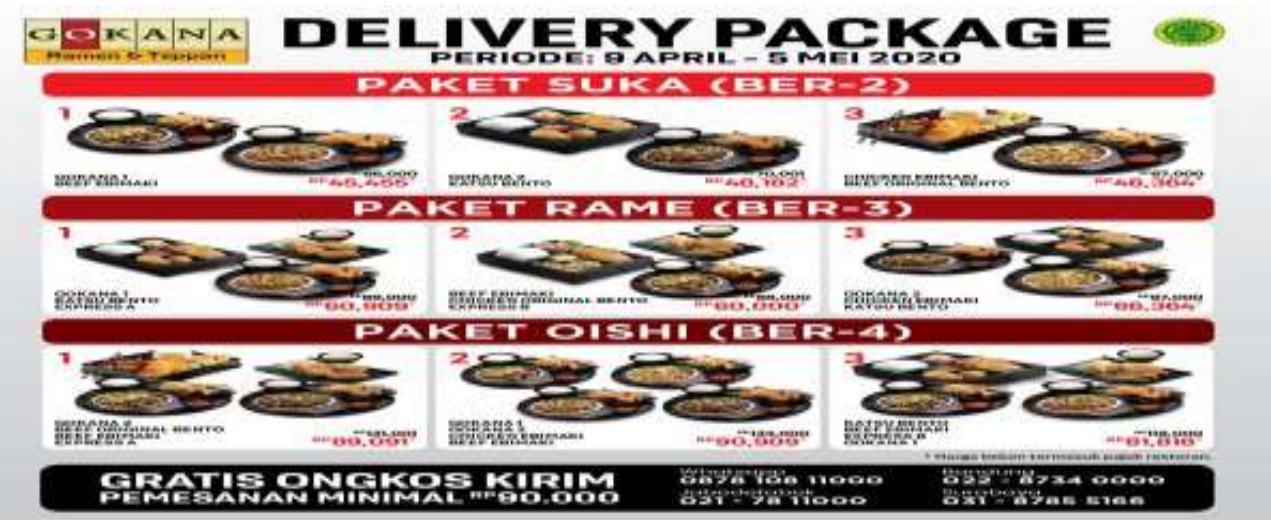


Gambar 2 Promosi pada tgl 9 April - 5 Mei 2020

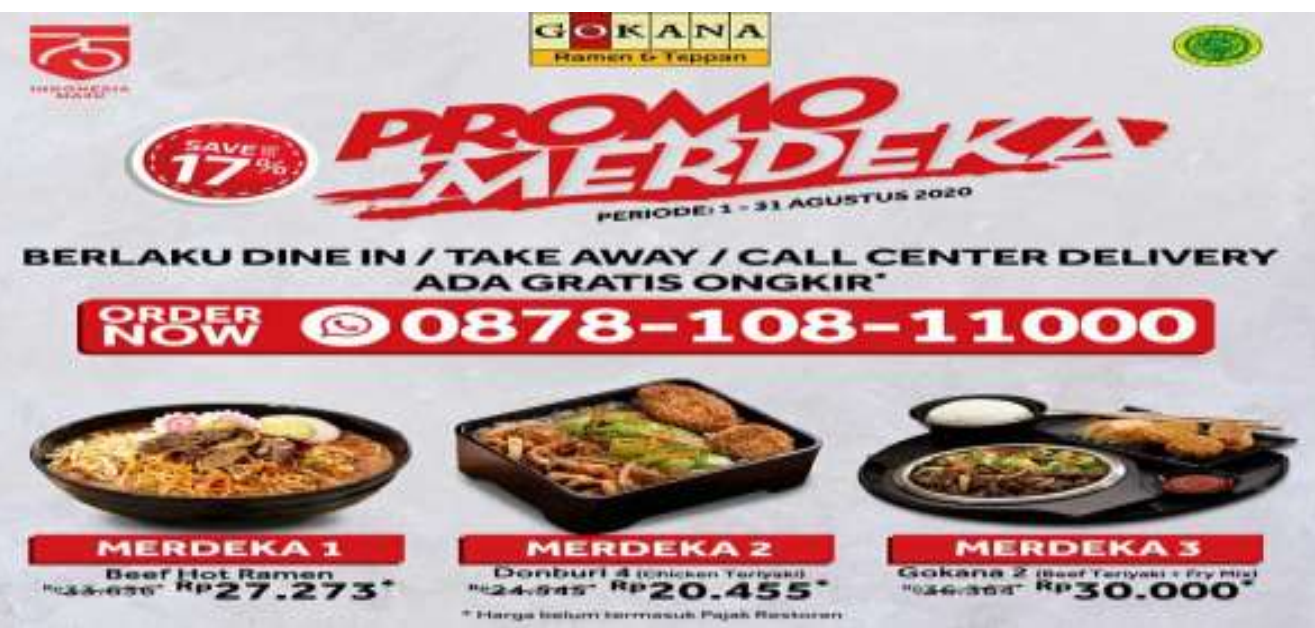

Gambar 3 Promo discont 17\% Untuk hari Kemerdekaan dan Ongkos Gratis pengantaran

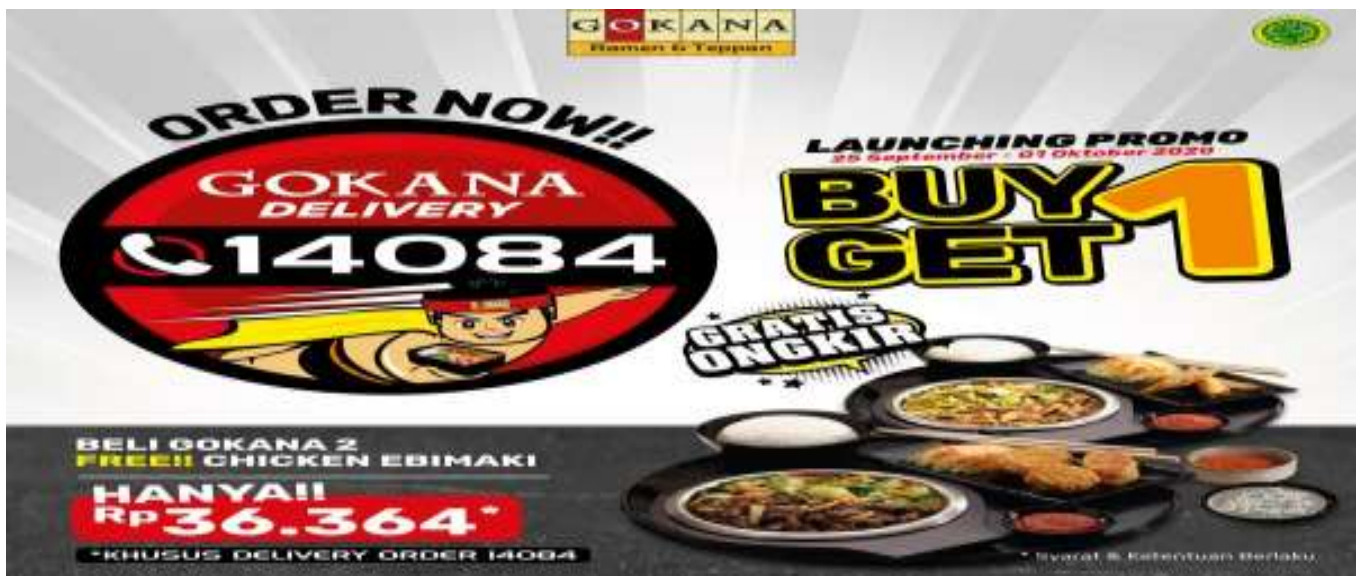

Gambar 4 Promo untuk buy 1 get 1 selama 25 September - 01 Oktober 2020

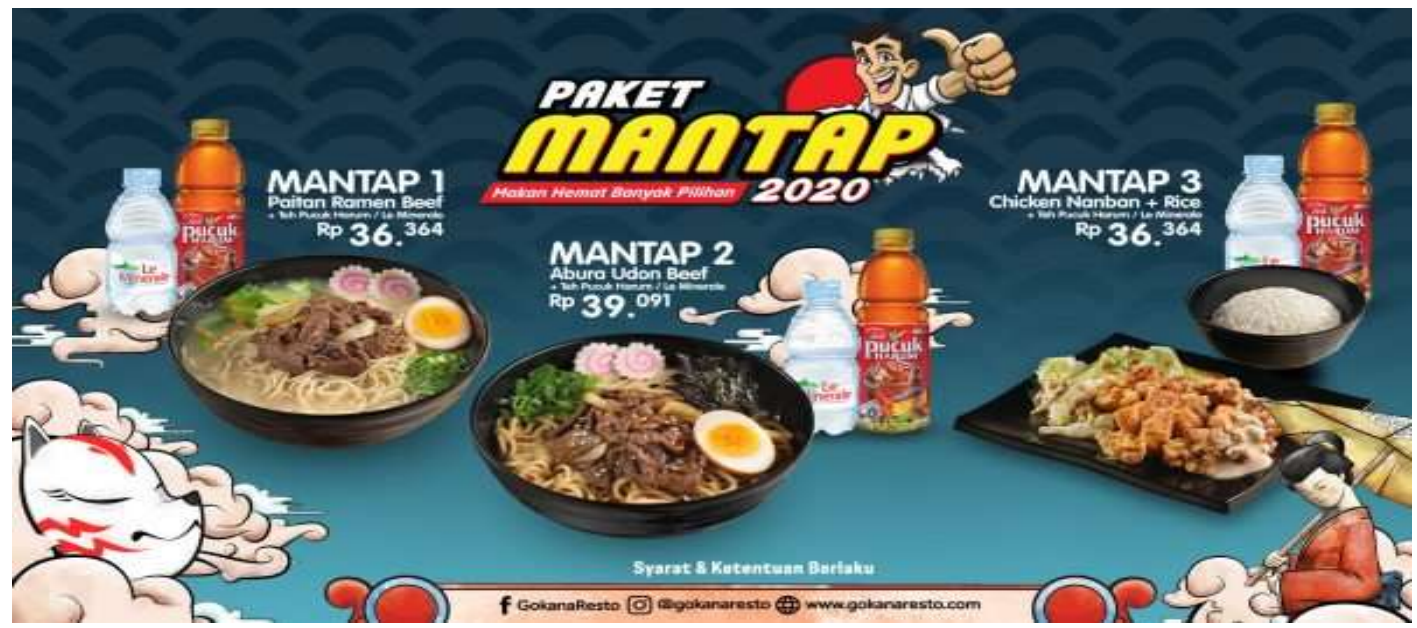

Gambar 5 Promo Paket Mantap 
Dari sebagian promosi yang sudah dijalankan selama pandemi seperti ini, walaupun promosi sudah dijalankan secara maksimal dari pihak Restoran, tapi pemasukan masih kurang optimal, hal ini disebabkan banyak faktor yang menyebabkan banyaknya penurunan,maka untuk meningkatkan lagi pembelian dari konsumen pihak restoranpun melalukan aktifitas penjualan melalui media online salah satunya melalui e-commerce.

Berikut yang sudah dilakukan oleh Restoran Gokana dengan sistem e-commence adalah sebagai berikut :

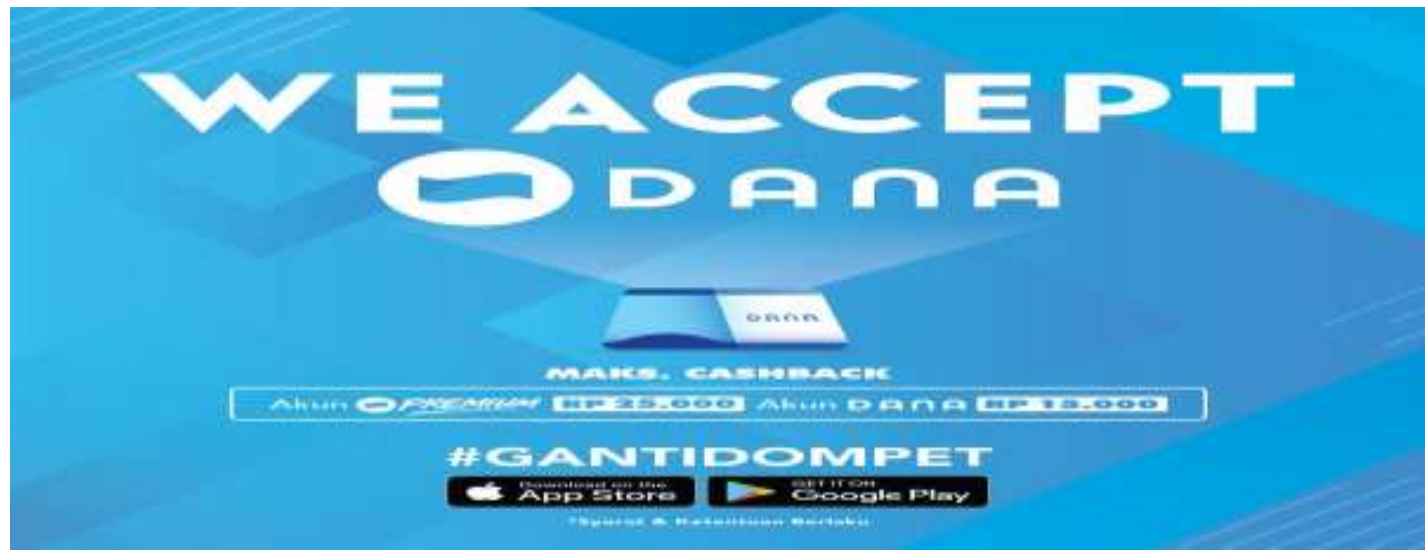

Gambar 6 Promo Pembayaran bekerjasama dengan Dana

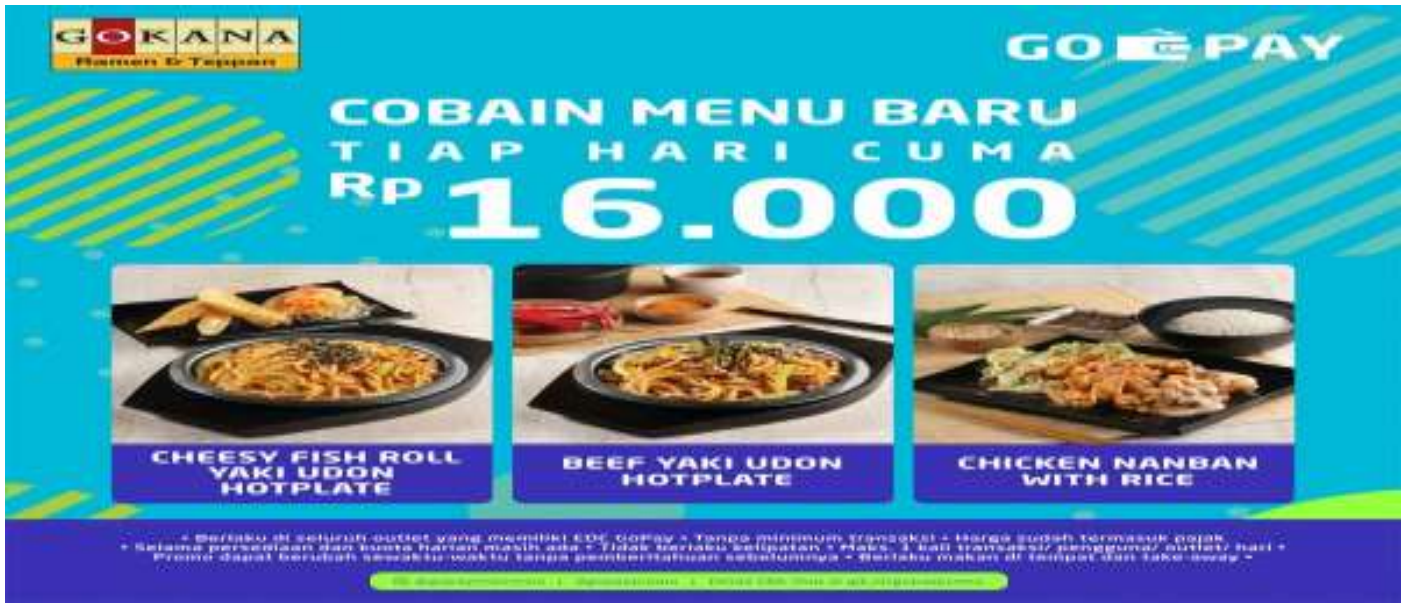

Gambar 7 Promo Pembayaran dengan Gopay

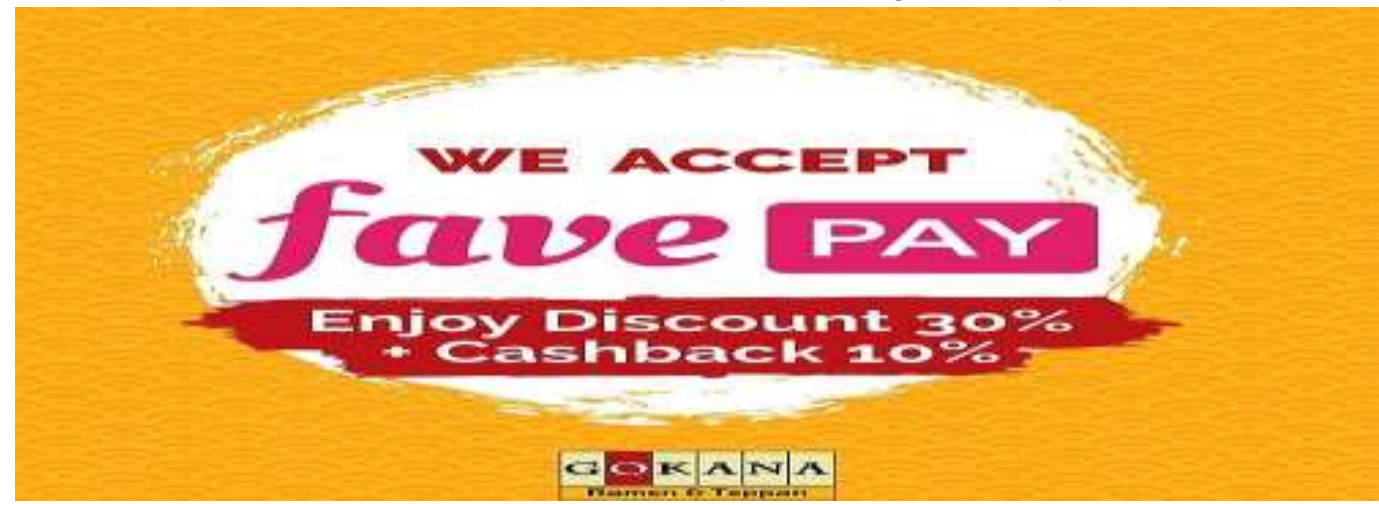

Gambar 8 Promo Pembayaran dengan Fave Pay

Jurnal Pemasaran Kompetitif, Vol. 04, No. 3 / Juni 2021 


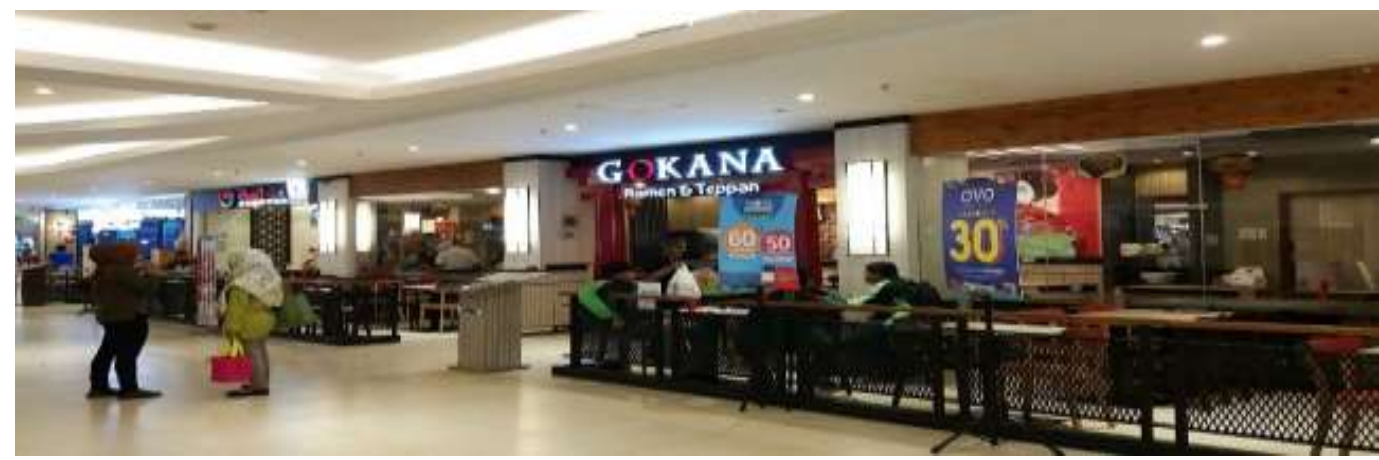

Gambar 9 Promo discount untuk pembayaran dengan OVO dan Gopay

Dari kegiatan ecommance diatas, dirasakan hasilnya pun masih kurang maksimal, hal ini karena banyak disebabkan oleh beberapa hal yaitu dari penjual diharapkan harus bisa memberikan pelayanan terbaik dan memberikan promosi yang menarik agar dapat menarik konsumen untuk membeli produknya, promosi yang sudah dilakukan Restoran Gokana tiap bulan itu ada perbedaan promosi dengan discont harga yang menarik, namun karena memang kondisi pandemi ini menyebabkan banyak konsumen yang menahan untuk membeli sesuatu yang terpenting dulu, maka ini juga yang meneyebabkan promosinya masih kurang maksimal hasilnya, dengan banyak pembatasan kegiatan diluar rumah juga menyebabkan banyaknya konsumen dan konsumen juga lebih selektif lagi dalam proses pembelian, akibat dari social distancing, konsumen beralih melakukan pembelian dengan low contact (online). take away, atau home delivery.

Sehubungan dengan situasi terkait pandemi COVID-19, telah penutupan beberapa wilayah kota Tangerang Selatan, hal mempengaruhi kelancaran proses pengiriman pesanan juga. Penutupan wilayah tersebut membuat beberapa layanan pengiriman (partner logistik) tidak bisa beroperasi atau pun mengalami hambatan berupa keterlambatan pengiriman. Selain itu sehubungan dengan social distancing, konsumen akan lebih menikmati gaya hidup cocooning. Istilah ini diperkenalkan oleh futurist Faith Popcorn dimana menunjukan orang yang hidup dalam kesendirian, menjauhi interaksi dengan orang lain secara langsung, ibaraat ulat kepompong yang membuat serat sutra dnengan membungkus dirinya sendiri. Dari kebijakan pemerintah juga mempengaruhi PSBB sesuai dengan Pergub 88 Tahun 2020, dimana sesmua kegiatan khususnya usaha kuliner juga diberikan adanya pembatasan waktu jam buka dan tutup dan tidak diperbolehkan konsumen makan di tempat, maka sudah dipastikan hal ini juga menyebabkan konsumen yang membeli menurun, maka dengan banyakanya aktifitas yang lebih banyak dibatasi sehingga menyebabkan volume penjualan menjadi menurun.

Berikut ini data volumen penjualan selama pandemi Restoran Gokana di Cabang Bintaro Plaza Tangerang Selatan adalah sebagai berikut :

Tabel 1 Volume Penjualan selama Masa Pandemi tahun 2020

\begin{tabular}{|c|c|}
\hline Bulan & Jumlah Porsi Makanan \\
\hline Januari & 5.493 \\
\hline Februari & 3.975 \\
\hline Maret & 1.257 \\
\hline April & 875 \\
\hline Mei & 654 \\
\hline Juni & 789 \\
\hline Juli & 891 \\
\hline Agustus & 1.325 \\
\hline September & 1.678 \\
\hline
\end{tabular}

Sumber: Gokana Cabang Bintaro Plaza 2020

Jurnal Pemasaran Kompetitif, Vol. 04, No. 3 / Juni 2021 
Dari data tabel diatas, bisa dilihat bahwa konsidi pandemi ini sangat mempengaruhi volume penjualan, bahkan pada masa pandemi ini juga banyak para pebisnis terutama di bidang kuliner juga berimbas juga tidak sedikit dari mereka juga banyak yang tutup akibat pandemi covid-19 ini karena banyak usaha yang tidak cukup kuat untuk menutupi semua biaya opersional yang telah dikeluarkan . Hal ini juga mempegaruhi juga Restoran Gokana Cabang Bintaro Plaza di Tangerang Selatan, lesunya bisnis ini juga bisa menyebabkan oprasional restoran banyak mengalami hambatan. Seperti data di Tabel 1.1 ini penjualan dari Januari sampai September penurunnnya sangat dratis sekali, pencapaain volume penjualannya masih jauh dari target yang diharapkan oleh perusahaan, jika dilhat perbandingannya kurang dari $50 \%$ perolahan penjualannya, ini jika tidak cepat disiati dengan strategi pemasaran yang benar dampaknya akan sangat bahaya bagi Restoran Gokana khususnya di Cabang Bintaro Plaza ini, dan umunya secara global juga mempengaruhi PT. Champ Resto Indonesia.

Dengan melihat volume penjualan yang terus menurun juga sudah otomatis berimbas juga pada keuntungan ( profit ) laba yang diperoleh, jika laba yang didapatkan terus menurun ini akan berimbas juga ke para karyawan juga, Restoran pasti akan mengurangi atau menekan biaya yang harus dikeluarkan semua yang berkaitan dengan operasional dari Restoran tersebut. Walaupun dengan kondisi sulit seperti ini Restoran Gokana tetap memberikan peluang semua karyawan untuk tetap bekerja dan memberikan pelayanan terbaik kepada konsumen, maka hal inilah yang membuat pihak Restoran Gokana mencari cara penjualan secara online yang diharapkan bisa memberikan dampak positif dan baik untuk Restoran tetap ada dan bisa memberikan yang terbaik kepada konsumen, dengan cara e-commence inilah diharapkan Restoran bisa meningkatkan volume penjualan sesuai target yang sudah ditetapkan.

Dari permasalahan yang sudah dijabarkan diatas selama pandemi covid-19 ini banyak mengerus semua ranah bisnis tanpa terkecuali di bidang kuliner, para pengusaha diharapakan lebih aktif dan invovatif lagi dalam cara penjual dengan memanfaatkan teknologi diharapkan bisa meningkatkan volume penjualannya kembali Maka dengan ini penulis tertarik ambil judul "E-Commerce Pada Masa Pandemi Covid-19 berpengaruh Terhadap Peningkatan Volume Penjualan Pada Restoran Gokana di Cabang Bintaro Plaza Tangerang Selatan"

Perumusan Masalah, Bagaimana e-commerce pada masa pandemi Covid-19 pada Restoran Gokana di Cabang Bintaro Plaza Tangerang Selatan. Bagaimana volume penjualan pada masa pandemi Covid-19 pada Restoran Gokana di Cabang Bintaro Plaza Tangerang Selatan. Bagaimana pengaruh e-commerce Pada Masa Pandemi Covid-19 Terhadap Peningkatan Volume Penjualan Pada Restoran Gokana di Cabang Bintaro Plaza Tangerang Selatan

TujuanPenelitian, Untuk mengetahui bagaimana e-commerce pada masa pandemi Covid19 pada Restoran Gokana di Cabang Bintaro Plaza Tangerang Selatan. Untukmengetahui bagaimana volume penjualanpada masa pandemi Covid-19 pada Restoran Gokana di Cabang Bintaro Plaza Tangerang Selatan. Untuk mengetahui pengaruh e-commerce Pada Masa Pandemi Covid-19 Terhadap Peningkatan Volume Penjualan Pada Restoran Gokana di Cabang Bintaro Plaza Tangerang Selatan

\section{KAJIAN LITERATUR}

"E-commerce merupakan proses membel i, menjual, atau memperdagangkan data , barang, atau jasa melalui internet (Turban et al., 2015: 7). Laudon dan Traver (2017: 8-9) mendefiniskan E-commerce sebagai transaksi komersial yang melibatkan pertukaran nilai 
yang dilakukan melalui atau menggunakan tekonologi digital antara individu. Dalam bertransaksi bisnis E-commerce menggunakan media internet, world wideweb, aplikasi atau browser pada perangkat selular atau mobile. Platform mobile adalah "pengembangan terbaru dalam infrastruktur Internet dari berbagai perangkat mobile seperti smartphone dan tablet melalui jaringan nirkabel ( wifi ) atau layanan telepon seluler". Lebih lanjut Laudon danTraver (2017: 11-12) mengungkapkan pada awal berkembangnya e-commerce, satusatunya media digital yang digunakan adalah web browser, akan tetapi saat ini media yang digunakan lebih banyak melalui aplikasi mobile.

Menurut Schiffan dalam Febriawan (2014:45), volume penjualan merupakan tingkat penjualan perusahaan untuk periode tertentu dalam satuan (unit/total/rupiah). Istilah volume penjualan telahmengalami perubahan-perubahan selama beberapa tahun. Awalnya para pengusaha menggunakan istilah ini untuk menunjukkan manajemen tenaga penjualan atau disebut juga menejemen penjualan, kemudianistilah tersebut diartikan secara lebih luas lagi dengan penjualan dari seluruh kegiatan pemasaran, distribusi fisik, penetapan harga jual, dan perencanaan produk tetapi sekarang istilah itu sudah dibedakan dengan lebih menunjukkan kegiatanpemasaran menjual produknya.

\section{E-COMMERCE PADA MASA PANDEMI COVID-19 BERPENGARUH TERHADAP PENINGKATAN VOLUME PENJUALAN PADA RESTORAN GOKANA CABANG BINTARO PLAZA TANGERANG SELATAN}

\begin{tabular}{|c|c|}
\hline E-Commerce $(\mathrm{X})$ & Volume Penjualan (Y) \\
\hline $\begin{array}{l}\text { 1. Manusia } \\
\text { 2. Kebijakan Publik } \\
\text { 3. Pemasaran \& Periklanan } \\
\text { 4. Layanan Pendukung } \\
\text { 5. Kemitraan Bisnis } \\
\text { Sumber : Turban et al. (2015: } \\
\text { 9) }\end{array}$ & $\begin{array}{l}\text { 1. Mencapai Volume } \\
\text { Penjualan } \\
\text { 2. Mendapatkan Laba } \\
\text { 3. Menunjang Pertumbuhan } \\
\text { Perusahaan } \\
\text { Sumber : Philip Kotler yang } \\
\text { dikutip Swastha dan Irawan } \\
\text { (2010:404) }\end{array}$ \\
\hline
\end{tabular}

\section{Gambar 10 Kerangka Pemikiran}

\section{METODE PENELITIAN}

Pada penelitian ini peneliti melakuakan penelitian di Restoran Gokana cabang Bintaro Plaza Tangerang Selatan. Penelitian dilakukan dari Bulan Februari sampai April 2021 dari survey awal, pengajuan proposal dan surat izin penelitian, konsultasi, pembagian kuesioner, pengolahan data hingga penyusunan jurnal.

Untuk riset ini menggunakan metode Asosiatif dimana menurut Sugiyono (2012:89) penelitian asosiatif merupakan penelitian yang dilakukan bertujuan dalam rangka mengetahui hubungan antara dua variabel atau lebih . Jumlah populasi Dalam penelitian ini yang dijadikan populasi adalah konsumen yang pernah membeli di Restoran Gokana di Bintaro Plaza secara online dan offline yang berjumlah 1.000 konsumen selama 6 bulan dari bulan April - September 2020.

Pada Teknik random sampling digunakan dalam menentukan sampel yang digunakan untuk penelitian ini , dan penarikan sampel dilakukkan secara acak dan setiap responden 
mempunyaii kemungkinan yang sama dipilih sebagai responden untuk penelitian . Jumlah sampel 91 responden diperoleh dengan menggunakan rumus slovin tingkat kesalahan 10\% Metode studi pustaka (I ibrary research ) dan studi lapangan ( field research) digunakan penulis dalam rangka mengumpulkan data. Pada Penelitiian ini, juga memanfatkan 2 macam yang sumber data yaitu sumber primer dan sumbersekunder agar diperoleh data yang relevan, accurate dan reliable

\section{HASIL DAN PEMBAHASAN}

1. Hasil Analisis Deskriptif a. E-Commerce

\begin{tabular}{|c|c|c|c|c|c|c|c|c|c|c|}
\hline \multirow{2}{*}{$\begin{array}{l}N \\
0\end{array}$} & \multirow{2}{*}{ Pernyataan } & ss & $\mathbf{S}$ & $\mathbf{N}$ & TS & STS & \multirow{2}{*}{ Total } & Total & Rata2 & \multirow{2}{*}{$\begin{array}{c}\text { KE } \\
T\end{array}$} \\
\hline & & 5 & & & & & & Skor & Skor & \\
\hline \multicolumn{11}{|c|}{ Manusia } \\
\hline 1 & $\begin{array}{l}\text { Penjual dalam } \\
\text { melayani pembeli } \\
\text { secara online } \\
\text { ramah dan bisa } \\
\text { memberikan } \\
\text { kenyakinan kepada } \\
\text { konsumen }\end{array}$ & 20 & 39 & 31 & 1 & 0 & 91 & 351 & 3,86 & B \\
\hline 2 & $\begin{array}{l}\text { Dalam pembelian } \\
\text { online konsumen } \\
\text { mendapatkan } \\
\text { banyak } \\
\text { kemudahan dalam } \\
\text { memilih kebutuhan } \\
\text { yang diharapkan }\end{array}$ & 10 & 27 & 46 & 8 & 0 & 91 & 312 & 3,42 & B \\
\hline & $\mathbf{F}$ & 30 & 66 & 77 & 9 & 0 & 182 & 663 & 7,28 & \\
\hline & $\%$ & 16,5 & 36,3 & 42,3 & 4,9 & 0 & 100 & & 3,64 & B \\
\hline \multicolumn{11}{|c|}{ Kebijakan Publik } \\
\hline 3 & $\begin{array}{l}\text { Aturan dari } \\
\text { pemerintah pada } \\
\text { masa pandemi } \\
\text { sekarang ini } \\
\text { mempermudah } \\
\text { anda dalam proses } \\
\text { pembelian online }\end{array}$ & 15 & 43 & 31 & 2 & 0 & 91 & 344 & 3,78 & B \\
\hline 4 & $\begin{array}{l}\text { Dari Aturan yang } \\
\text { mengharuskan } \\
\text { adanya social } \\
\text { distancing, } \\
\text { konsumen beralih } \\
\text { melakukan } \\
\text { pembelian } \\
\text { dengan lowcontact } \\
\text { (online),take away, } \\
\text { atau home } \\
\text { delivery. }\end{array}$ & 21 & 41 & 26 & 3 & 0 & 91 & 353 & 3,88 & B \\
\hline
\end{tabular}


ISSN NO. (PRINT) 2598-0823, (ONLINE) 2598-2893

\begin{tabular}{|c|c|c|c|c|c|c|c|c|c|c|}
\hline \multicolumn{2}{|r|}{$\mathbf{F}$} & \multirow{2}{*}{$\begin{array}{c}36 \\
19,8\end{array}$} & \multirow{2}{*}{$\begin{array}{c}84 \\
46,1 \\
5\end{array}$} & \multirow{2}{*}{$\begin{array}{c}57 \\
31,3\end{array}$} & \multirow{2}{*}{\begin{tabular}{|c|}
5 \\
2,75
\end{tabular}} & \multirow{2}{*}{$\begin{array}{l}0 \\
0\end{array}$} & \multirow{2}{*}{$\begin{array}{l}182 \\
100\end{array}$} & \multirow[t]{2}{*}{697} & \multirow{2}{*}{\begin{tabular}{|l|}
7,66 \\
3,83
\end{tabular}} & \multirow[b]{2}{*}{ B } \\
\hline & $\%$ & & & & & & & & & \\
\hline \multicolumn{10}{|c|}{ Pemasaran \& Periklanan } & \\
\hline 5 & $\begin{array}{l}\text { Promosi yang ada } \\
\text { di Restoran sudah } \\
\text { sesuai dengan apa } \\
\text { yang diharapkan } \\
\text { oleh konsumen }\end{array}$ & 18 & 41 & 32 & 0 & 0 & 91 & 350 & 3,85 & B \\
\hline 6 & $\begin{array}{l}\text { Strategi promosi } \\
\text { pemasaran yang } \\
\text { sudah dijalankan } \\
\text { oleh Restoran ini } \\
\text {,membuat anda } \\
\text { lebih memilih } \\
\text { dengan low contact } \\
\text { (online),take away } \\
\text { atau home } \\
\text { delivery. }\end{array}$ & 15 & 52 & 22 & 2 & 0 & 91 & 353 & 3,88 & B \\
\hline & $\mathbf{F}$ & 33 & 93 & 54 & 2 & 0 & 182 & 703 & 7,73 & \\
\hline & $\%$ & 18,1 & 51,1 & 29,7 & 1,1 & 0 & 100 & & 3,86 & B \\
\hline \multicolumn{11}{|c|}{ Layanan Pendukung } \\
\hline 7 & $\begin{array}{l}\text { Pemanfaatan } \\
\text { sosial media, e- } \\
\text { commerce atau } \\
\text { marketplace } \\
\text { mempermudahkan } \\
\text { anda untuk } \\
\text { membeli }\end{array}$ & 21 & 39 & 31 & 0 & 0 & 91 & 354 & 3,89 & B \\
\hline 8 & $\begin{array}{l}\text { Kemudahan akses } \\
\text { internet pada saat } \\
\text { ini mempermudah } \\
\text { anda dalam } \\
\text { mencari informasi } \\
\text { kebutuhan yang } \\
\text { anda butuhkan }\end{array}$ & 16 & 53 & 19 & 3 & 0 & 91 & 355 & 3,9 & B \\
\hline & $F$ & 37 & 92 & 50 & 3 & 0 & 182 & 709 & 7,79 & \\
\hline & $\%$ & 20,3 & 50,6 & 27,5 & 1,6 & 0 & 100 & & 3,89 & B \\
\hline \multicolumn{11}{|c|}{ Kemitraan Bisnis } \\
\hline 9 & $\begin{array}{l}\text { Kerjasama antara } \\
\text { Restoran dengan } \\
\text { gojek dan grab } \\
\text { dalam pengiriman } \\
\text { sudah sesuai } \\
\text { jadwal dan tepat } \\
\text { waktu sampai di } \\
\text { konsumen }\end{array}$ & 16 & 42 & 33 & 0 & 0 & 91 & 347 & 3,81 & B \\
\hline $\begin{array}{l}1 \\
0\end{array}$ & $\begin{array}{l}\text { Informasi produk- } \\
\text { produk yang ada } \\
\text { di restoran dengan } \\
\text { mudah anda } \\
\text { temukan di sosial } \\
\text { media, e- }\end{array}$ & 15 & 41 & 33 & 2 & 0 & 91 & 342 & 3,75 & B \\
\hline
\end{tabular}


ISSN NO. (PRINT) 2598-0823, (ONLINE) 2598-2893

\begin{tabular}{|c|c|c|c|c|c|c|c|c|c|}
\hline $\begin{array}{l}\text { commerce atau } \\
\text { marketplace }\end{array}$ & & & & & & & & & \\
\hline F & 31 & 83 & 66 & 2 & 0 & 182 & 689 & 8,58 & \\
\hline Total Jawaban & 167 & 418 & 304 & 21 & 0 & 910 & & & \\
\hline \hline $\begin{array}{c}\text { Persentase Jawaban } \\
(\%)\end{array}$ & 18,3 & 46 & 33,4 & 2,3 & 0 & 100 & $\begin{array}{c}\text { Rata- } \\
\text { rata }\end{array}$ & 3,80 & B \\
\hline
\end{tabular}

Sumber : Data Primer Yang Diolah 2021

Diketahui dari data tabel di atas, skor rata-rata E-Commerce sebesar 3,80 termasuk dalam skala interval 3,40-4,19 interpretasi Baik yang dapat diartikan responden memiliki persepsi pembelian online pada Restoran Gokana cabang Bintaro Plaza Tangerang Selatan adalah baik.

\section{b. Volume Penjualan}

\begin{tabular}{|c|c|c|c|c|c|c|c|c|c|c|}
\hline \multirow{3}{*}{$\begin{array}{l}\mathbf{N} \\
\mathbf{0}\end{array}$} & \multirow{3}{*}{ Pernyataan } & $c c$ & $c$ & I & TC & CTC & \multirow{3}{*}{ Total } & Total & Rata2 & \multirow{3}{*}{$\begin{array}{l}\text { KE } \\
T\end{array}$} \\
\hline & & & & & & & & Skor & Skor & \\
\hline & & 5 & 4 & 3 & & & & & & \\
\hline \multicolumn{11}{|c|}{ Mencapai Volume Penjualan } \\
\hline 1 & $\begin{array}{l}\text { Anda sudah merasa } \\
\text { puas dengan } \\
\text { pelayanan dan rasa } \\
\text { yang diberikan oleh } \\
\text { restoran ini }\end{array}$ & 17 & 45 & 28 & 1 & 0 & 91 & 351 & 3,86 & B \\
\hline 2 & $\begin{array}{l}\text { Anda sering } \\
\text { merekomendasikan } \\
\text { restoran ini kepada } \\
\text { orang lain }\end{array}$ & 9 & 28 & 45 & 9 & 0 & 91 & 310 & 3,41 & B \\
\hline 3 & $\begin{array}{l}\text { Restoran ini sudah } \\
\text { menyajikan rasa } \\
\text { yang beda dari } \\
\text { restoran lain } \\
\text { sehingga anda selalu } \\
\text { datang ke tempat ini }\end{array}$ & 17 & 43 & 30 & 1 & 0 & 91 & 349 & 3,83 & B \\
\hline & $\mathbf{F}$ & 43 & 116 & 103 & 11 & 0 & 273 & 1010 & 11,1 & \\
\hline & $\%$ & 15,75 & 42,5 & 37,73 & 4,02 & 0 & 100 & & 3,7 & B \\
\hline & & & Men & patkan & Laba & & & & & \\
\hline 4 & $\begin{array}{l}\text { Harga yang diberikan } \\
\text { oleh restoran ini } \\
\text { sudah sangat } \\
\text { bersaing dengan } \\
\text { restoran lain } \\
\text { sehingga anda akan } \\
\text { kembali datang ke } \\
\text { sini }\end{array}$ & 15 & 41 & 32 & 3 & 0 & 91 & 341 & 3,75 & B \\
\hline 5 & $\begin{array}{l}\text { Rasa yang nikmat } \\
\text { membuat anda tidak }\end{array}$ & 22 & 36 & 32 & 1 & 0 & 91 & 352 & 3,87 & B \\
\hline
\end{tabular}

Jurnal Pemasaran Kompetitif, Vol. 04, No. 3 / Juni 2021 
ISSN NO. (PRINI) 2598-0823, (ONLINE) 2598-2893

\begin{tabular}{|c|c|c|c|c|c|c|c|c|c|c|}
\hline & $\begin{array}{l}\text { memperdulikan } \\
\text { harga makanan di } \\
\text { Restoran ini }\end{array}$ & & & & & & & & & \\
\hline 6 & $\begin{array}{l}\text { Restoran ini } \\
\text { mempunya ciri khas } \\
\text { yang membuat anda } \\
\text { terus akan datang ke } \\
\text { sini }\end{array}$ & 13 & 51 & 27 & 0 & 0 & 91 & 350 & 3,85 & B \\
\hline & $\mathbf{F}$ & 50 & 128 & 91 & 4 & 0 & 273 & 1043 & 11,47 & \\
\hline & $\%$ & 18,3 & 46,9 & 33,3 & 1,5 & 0 & 100 & & 3,82 & B \\
\hline & & Me & unjang & ertumb & han F & usa & & & & \\
\hline 7 & $\begin{array}{l}\text { Pembelian secara } \\
\text { online tidak } \\
\text { menghalangi anda } \\
\text { tetap membeli } \\
\text { makanan di Restoran } \\
\text { ini }\end{array}$ & 15 & 41 & 32 & 3 & 0 & 91 & 341 & 3,75 & $B$ \\
\hline 8 & $\begin{array}{l}\text { Kerjasama yang baik } \\
\text { antara pihak } \\
\text { Restoran dan deliveri } \\
\text { ( Gojek atau Grab ) } \\
\text { bisa datang tepat } \\
\text { waktu yang dijanjikan }\end{array}$ & 14 & 42 & 35 & 0 & 0 & 91 & 343 & 3,77 & B \\
\hline 9 & $\begin{array}{l}\text { Saat pembayaran } \\
\text { pembelian secara } \\
\text { online, anda tidak } \\
\text { mendapatkan } \\
\text { kesulitan }\end{array}$ & 15 & 45 & 31 & 0 & 0 & 91 & 348 & 3,82 & B \\
\hline $\begin{array}{l}1 \\
0\end{array}$ & $\begin{array}{l}\text { Anda dapat dengan } \\
\text { mudah mengakses } \\
\text { Restoran ini dan } \\
\text { melihat semua } \\
\text { produk dan promo } \\
\text { yang ada }\end{array}$ & 30 & 39 & 22 & 0 & 0 & 91 & 372 & 4,08 & B \\
\hline & $\mathbf{F}$ & 74 & 167 & 120 & 3 & 0 & 364 & 1404 & 15,42 & \\
\hline & $\%$ & 20,33 & 45,88 & 32,97 & 0,82 & 0 & 100 & & 3,87 & B \\
\hline & Total Jawaban & 167 & 411 & 314 & 18 & 0 & 910 & & & \\
\hline & $\begin{array}{c}\text { ersentase Jawaban } \\
(\%)\end{array}$ & 18,35 & 45,17 & 34,5 & 1,98 & 0 & $100 \%$ & Rata2 & 3,79 & 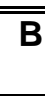 \\
\hline
\end{tabular}

Sumber : Data Primer Yang Diolah 2021

Dari tabel di atas diketahui skor rata-rata Volumen Penjualan sebesar 3,79 masuk pada interval 3,40-4,19 interpretasi Baik berarti responden mempunyaii persepsi yaitu pada Restoran Gokana cabang Bintaro Plaza Tangerang Selatan adalah baik.

2. Hasil Uji Validitas dan Reliabilitas

a. Uji Validitas untuk Variabel E-Commerce $(X)$

\begin{tabular}{|c|c|c|c|}
\hline \multicolumn{4}{|c|}{ E-Commerce $(\mathrm{X})$} \\
\hline No Kuesioner & $\mathrm{R}$ hitung & $\mathrm{R}$ tabel & Keterangan \\
\hline 1 & 0.413 & 0,1735 & Valid \\
\hline
\end{tabular}


ISSN NO. (PRINT) 2598-0823, (ONLINE) 2598-2893

\begin{tabular}{|c|c|c|c|}
\hline 2 & 0.324 & 0,1735 & Valid \\
\hline 3 & 0.332 & 0,1735 & Valid \\
\hline 4 & 0.539 & 0,1735 & Valid \\
\hline 5 & 0.737 & 0,1735 & Valid \\
\hline 6 & 0.502 & 0,1735 & Valid \\
\hline 7 & 0.758 & 0,1735 & Valid \\
\hline 8 & 0.724 & 0,1735 & Valid \\
\hline 9 & 0.662 & 0,1735 & Valid \\
\hline 10 & 0.503 & 0,1735 & Valid \\
\hline
\end{tabular}

Sumber : Data hasil pengolahan SPSS versi 21.

b. Uji Validitas untuk Varibel Volume Penjualan ( $Y$ )

\begin{tabular}{|c|c|c|c|}
\hline \multicolumn{4}{|c|}{ Volume Penjualan $(\mathrm{Y})$} \\
\hline No Kuesioner & $\mathrm{R}$ hitung & $\mathrm{R}$ tabel & Keterangan \\
\hline 1 & 0.490 & 0,1735 & Valid \\
\hline 2 & 0.359 & 0,1735 & Valid \\
\hline 3 & 0.505 & 0,1735 & Valid \\
\hline 4 & 0.425 & 0,1735 & Valid \\
\hline 5 & 0.437 & 0,1735 & Valid \\
\hline 6 & 0.398 & 0,1735 & Valid \\
\hline 7 & 0.603 & 0,1735 & Valid \\
\hline 8 & 0.533 & 0,1735 & Valid \\
\hline 9 & 0.494 & 0,1735 & Valid \\
\hline 10 & 0.583 & 0,1735 & Valid \\
\hline
\end{tabular}

Sumber : Data hasil pengolahan SPSS versi 21.

Berdasarkan Tabel 4.11 dan Tabel 4.12 diatas bahwa darinilai keseluruhan ( $r_{\text {hitung }}$ ) memiliki nilai lebih besar daripada $r_{\text {tabel }}(0,1716)$, dan disimpulkan bahwa keseluruhan butirr pertanyaan tersebut adalah Valid karena $r_{\text {hitung }}>r_{\text {tabel. }}$

Hasil Uji Reliabilitas

\begin{tabular}{|c|l|c|c|c|}
\hline No & \multicolumn{1}{|c|}{ Variabel } & $\begin{array}{c}\text { Alpha } \\
\text { Cronbach }\end{array}$ & Syarat & Keterangan \\
\hline 1 & E-Commerce $(\mathrm{X})$ & 0.733 & 0.600 & Reliabel \\
\hline 2 & Volume Penjualan $(\mathrm{Y})$ & 0.706 & 0.600 & Reliabel \\
\hline
\end{tabular}

Sumber : Data Pengolahan SPSS versi 21

\section{Uji Analisis Regresi Linier Sederhana}

\section{Hasil Uji Regresi Linier Sederhana}

Coefficients $^{\mathrm{a}}$

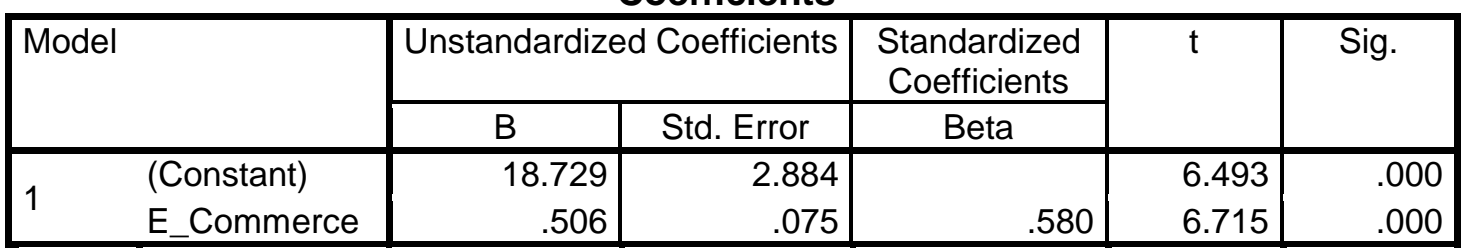

a. Dependent Variable: Vol_Penjualan

Sumber : Hasil olahan data SPSS Versi 21 
Sudah diketahui bahwa persamaan umum regresi analisis linier sederhana adalah : $\mathbf{Y}=\mathbf{a}+\mathbf{b} \mathbf{X}$. Dari hasil tebel diatas diketahui "a" berada pada Konstan sebesar 18,729 dan "b" berada pada e-commerce dengan perolehan angka 0,506 artinya persamaaan regresi linier sederhana didapatkan adalah : $Y=18,729+0,506 X$ artinya maka dapat dijelaskan sebagai berikut :

a. Persamaan regresi yang diperoleh yaitu $Y=18,729+0,506(X)$ dapat diinterpretasikan bahwa perubahan $Y$ searah dengan perubahan $X$ dimana nilai $Y$ akan meningkat jika nilai $X$ meningkat, dan sebaliknya nilai $Y$ akan turun jika $X$ menurun. Sehingga disimpulkan bahwa e-commerce berpengaruh positif terhadap volume penjualan.

b. Dari persamaan regresi di atas pula dapat disimpulkan apabila e-commerce bertambah 1, maka nilai rata - rata volume penjualan akan bertambah sebesar 0,506 tiap bulan atau setiap e-commerce bertambah 10, maka nilai rata - rata volume penjualan bertambah pula sebesar 5,0 setiap bulan

1. Uji Koefisien Korelasi Product Moment ( R )

Hasil Uji Koefesien Korelasi

Model Summary

\begin{tabular}{|l|r|r|r|r|}
\hline Model & \multicolumn{1}{|c|}{$\mathrm{R}$} & $\mathrm{R}$ Square & $\begin{array}{c}\text { Adjusted } \mathrm{R} \\
\text { Square }\end{array}$ & $\begin{array}{r}\text { Std. Error of } \\
\text { the Estimate }\end{array}$ \\
\hline 1 & $.580^{\mathrm{a}}$ & .336 & .329 & 2.920 \\
\hline
\end{tabular}

a. Predictors: (Constant), E_Commerce

Sumber : Hasil olahan data SPSS Versi 21

Pedoman interpretasi Koefesien Korelasi

\begin{tabular}{|c|c|}
\hline Interval Koefesien & Tingkat Pengaruh \\
\hline $0,00-0,199$ & Sangat rendah \\
\hline $0,200-0,399$ & Rendah \\
\hline $\mathbf{0 , 4 4 0}-\mathbf{0 , 5 9 9}$ & Sedang/Cukup \\
\hline $0,600-0,799$ & Kuat \\
\hline $0,800-1,099$ & Sangat kuat \\
\hline
\end{tabular}

Sumber : Sugiyono (2012:216)

Dari hasil perhitungan Correlation coficient pearson diperoleh nilai koefesien korelasi Rxy sebesar 0,580, maka ini menunjukkan adanya hubungan yang sedang atau, cukup antara e-commerce terhadap volume penjualan, karena nilai 0,580 terletak diantara nilai koefisien korelasi 0,440-0,599

\section{Uji Koefisien Determinasi}

\section{Hasil Uji Koefesien Determinasi}

Model Summary

\begin{tabular}{|l|r|r|r|r|}
\hline Model & \multicolumn{1}{|c|}{$\mathrm{R}$} & $\mathrm{R}$ Square & $\begin{array}{c}\text { Adjusted R } \\
\text { Square }\end{array}$ & $\begin{array}{c}\text { Std. Error of the } \\
\text { Estimate }\end{array}$ \\
\hline 1 & $.580^{\circ}$ & .336 & .329 & 2.920 \\
\hline
\end{tabular}

a. Predictors: (Constant), E_Commerce

Sumber : Hasil olahan data SPSS Versi 21 
Diketahui dari tabel di atas nilai koefisien determinasi ( $\mathrm{R}$ Square )yang diperoleh sebesar 0.336. Hal ini berarti 33,6\%pengaruh e-commerce terhadap volume penjualan, sedangkan sisanya $66,4 \%$ dipengaruhi oleh variabel-variabel lain yang tidak diteliti seperti harga, store atmosphere, kualitas produk dan lain-lain.

\section{Uji Signifikasi (Uji T)}

\section{Hasil Uji Hipotesis / Uji t}

Coefficients $^{\mathrm{a}}$

\begin{tabular}{|c|c|c|c|c|c|}
\hline \multirow[t]{2}{*}{ Model } & \multicolumn{2}{|c|}{$\begin{array}{l}\text { Unstandardized } \\
\text { Coefficients }\end{array}$} & $\begin{array}{c}\text { Standardized } \\
\text { Coefficients }\end{array}$ & $\mathrm{T}$ & Sig. \\
\hline & $\mathrm{B}$ & Std. Error & Beta & & \\
\hline $\begin{array}{l}\text { (Constant) } \\
\text { E_Commerc } \\
\text { e }\end{array}$ & $\begin{array}{r}18.729 \\
.506\end{array}$ & $\begin{array}{r}2.884 \\
.075\end{array}$ & .580 & $\begin{array}{l}6.493 \\
6.715\end{array}$ & $\begin{array}{l}.000 \\
.000\end{array}$ \\
\hline
\end{tabular}

a. Dependent Variable: Vol_Penjualan

Sumber : Hasil olahan data SPSS Versi 21

Dari perhitungan tabel Hasil Uji t, diketahui $t_{\text {tabel }}$ adalah 1,662 dengan df : $91-2=89$. berdasarkan data tabel diatas diketahui $t$ hitung $>t_{\text {tabel }}$ yaitu sebesar $6,493>1,662$, hal ini dikatakan positif, dan diperkuat dengan signifikansi $0,000<0,10$ sehingga artinya $\mathrm{H}_{0}$ ditolak dan $\mathrm{H}_{\mathrm{a}}$ diterima, terdapat pengaruh yang positif dan signifikan antara e-commerce terhadap volume penjualan

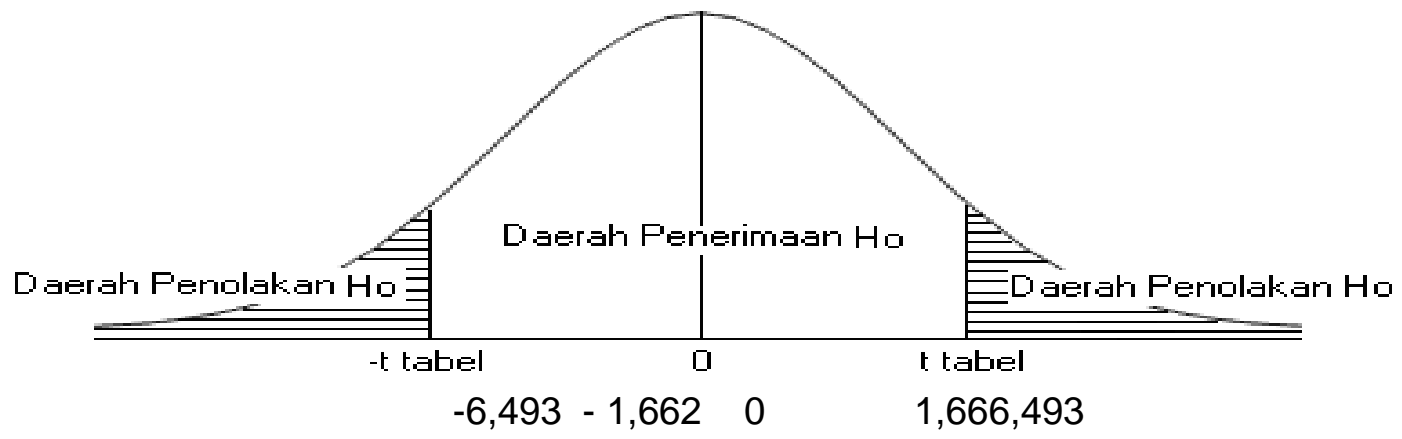

Gambar 11 Kriteria Penentuan Penerimaan Hipotesis

\section{KESIMPULAN}

1. Kesimpulan

Berdasarkan pembahasan dan hasil penelitian, mengenai pengaruh E-commerce (X) terhadap Volume Penjualan ( $\mathrm{Y}$ ) pada Restoran Gokana di Cabang Bintaro Plaza Tangerang Selatan, maka dapat diperoleh kesimpulan sebagai berikut :

a. E-Commerce pada Restoran Gokana di Cabang Bintaro Plaza Tangerang Selatan dari 10 pertanyaan dengan jumlah 91 responden, dari pernyataan pada variabel $(X)$, yang menjawab sangat setuju, setuju, netral, tidak setuju dan sangat tidak setuju sebesar $(18,3 \%+46 \%+33,4 \%+2,3 \%+0 \%)=100 \%$ dengan rata - rata 3,80 termasuk dalam rentang skala $3.40-4.19$ termasuk kriteria Baik . Hal ini dapat bisa dilihat dari jawaban responden pada butir pernyataan pada indikator Layanan Pendukung yaitu 
Pemanfaatan sosial media, e-commerce atau market place mempermudah anda untuk membeli "yang mendapatkan skor 3,89 dengan kategori Baik

b. Volume Penjualan pada Restoran Gokana di Cabang Bintaro Plaza Tangerang Selatan, dari 10 pertanyaan dengan jumlah 91 responden, dimana jawaban pernyataan pada variabel ( $Y$ ), yang menjawab sangat setuju, setuju, netral, tidak setuju dan sangat tidak setuju sebesar $(18,35 \%+45,17 \%+34,5 \%+$ $1,98 \%+0 \%)=100 \%$. dengan rata - rata skor 3,79 termasuk pada rentang skala adalah 3.40 - 4.19 dengan kriteria Baik. Hal ini dapat dilihat dari jawaban responden pada butir pernyataan pada indikator menunjang pertumbuhan perusahaanyaitu "Anda dapat dengan mudah mengakses Restoran ini dan melihat semua produk dan promo yang ada" mendaptakan skor 4.08 dengan kategori Baik.

c. Terdapat pengaruh positif dan signifikan antara e-commerceterhadap Volume Penjualan dengan persamaan regresi $Y=18,729+0,506$ Xdapat diartikan bahwa apabila e-commercebertambah 1, maka nilai rata - rata volume penjualan tiap bulan akan bertambah sebesar 0,506 atau setiapnilai $e$ commerce bertambah 10 , maka nilai rata - rata minatbeli tiap bulan bertambah pula sebesar 5,06 . nilai koefisien korelasi $(R)$ sebesar0,580, sehingga dapat disimpulkna bahwa e-commerce $(\mathrm{X})$ memiliki tingkat pengaruh berkekuatan sedang/cukup terhadap volume penjualan $(\mathrm{Y})$ dan koefisien determinasi $\left(R^{2}\right)$ yang didapat sebesar 0.336 . Hal ini berarti $33,6 \%$ pengaruh ecommerceterhadap volume penjualan sedangkan sisanya $66,4 \%$ dipengaruhi oleh variabel-variabel lain yangtidak diteliti. Uji hipotesis diperoleh $\mathrm{t}$ hitung $>\mathrm{t}$ tabel yaitu sebesar 6,493 > 1,662, maka dapat dikatakan positif, hal ini diperkuat dengan signifikansi $0,000<0,10$ menunjukkan $\mathrm{H}_{0}$ ditolak dan $\mathrm{H}_{\mathrm{a}}$ diterima yang berarti terdapat pengaruh yang positif dan signifikan antara ecommerceterhadap volume penjualan.

\section{Saran}

Dari analisa yang telah dilakukan dalam penelitian ini, maka penulis memberikan saran sebagai berikut:

a. Pada variabel e-commerce $(\mathrm{X})$ skor terendah ada pada Manusia yaitu tentang "Penjual dalam melayani pembeli secara online ramah dan bisa memberikan kenyakinan kepada konsumen " untuk diharapkan Restaurant Gokana dapat meningkatan pelayanan sebagaifaktor utama dalam proses perkembangan sebuah bisnis. Untuk itu pelayanan yang terbaik kepada para konsumen menjadi sebuah keharusn. Konsumen tidak hanya menginginkan penjual yang memberikan pelayanan cepat tanggap saja tetapi juga menginankan penjual yang baik. Yang dimaksud dengan Penjual yang baik disini adalh penjual yang ramah, sabar, dan jujur dalam melayani pelanggan, sehingga membuat konsumen merasa nyaman dan memiliki tingkat kepercayaan yang tinggi.

b. Pada variabel Volume Penjualan (Y) skor terendah ada Mencapai Volume Penjualanyaitu tentang "Anda sering merekomendasikan restoran ini kepada orang lain", maka dari itu peranan perusahaan yang harus lebih giat lagi untuk memberikan promo-promo yang menarik agar konsumen membeli lebih banyak, ditambah varian menu dan rasa harus punya ciri khas yang berbeda dari produk lain dan ini wajib dimilki oleh pihak pengusaha makanan, karena dengan produk yang khas dan beda akan memberikan nilai plus dimata pembeli sehingga bisa penjadi pelanggan tetap. Selain itu Restaurant Gokanan juga diharapkan dapat meningkatkan pelayanan dengan melakukan pengiriman pemesanan tepat waktu. Berhubung jumlah pengguna media sosial kini 
semakin meningkat, pihak restoran pun harus memanfaatkan kesempatan ini untuk mendapatkan feedback dari para pelanggan.Caranya bisa dengan membuat akun di media sosial, lalu undang para pelanggan untuk memberi pendapat lewat kolom komentar, memberikan rating bintang, mereferensikan teman-teman mereka dan lain sebagainya

\section{DAFTAR PUSTAKA}

Abdullah, M Ma'ruf. (2014) Manajemen dan Evaluasi Kinerja Karyawan. Yogyakarta: Aswaja Pressindo.

Ahmadi, Candra Dan Dadang Hermawan (2013). E-Business \& E-Commerce. Jakarta : ANDI OFFSET

Alma, Buchari. (2014). Manajemen Pemasaran dan Pemasaran Jasa. Bandung : Alfabeta

Arikunto, Suharsimi. (2012). Prosedur Penelitian Suatu Pendekatan Praktek.Jakarta: Rineka Cipta

Arikunto, Suharsimi. (2012). Prosedur Penelitian.Jakarta:n Rineka Cipta.

Asim. (2019) Pengaruh E-Commerce dan Strategi Pemasaran terhadap peningkatan penjualan pada Sophie Paris Bussines Center Nova Dwi Ayuning di Jonggol Kabupaten Bogor. Journal of Business Studies, Vol. 4, No. 2, Tahun 2019, ISSN no. 2443-3837, hal. 84-93. Jakarta : Universitas Respati Indonesia

Ghozali, Imam. (2013). Aplikasi Analisis Multivariate dengan Program IBM SPSS 21. Edisi 7. Semarang : Badan Penerbit Universitas Diponegoro

Handoko, Hani T. (2013). Manajemen. Edisi 2. Yogyakarta : BPPE

Hasibuan , M.S. (2012) .Manajemen Sumber Daya Manusia. Jakarta: PT Bumi Aksara

Himawan, Asep Saefullah, Sugeng Santoso (2014). Analisa dan Perancangan Sistem Informasi Penjualan Online (E-Commerce) pada CV Selaras Batik Menggunakan Analisis Deskriptif. Scientific Journal of Informatics, Vol.1 No. 1, Mei 2014, hal. 58-59

Kotler, Philip \& Gary Amstrong. (2014). Manajemen Pemasaran . Edisi 13. Jakarta: Erlangga

Kotler, Philip and Kevin Lane Keller. (2016). Marketing Management, 15th Edition, Pearson Education, Inc.

Laudon, K. C., \& Traver, C. G. (2017). E-Comerse 2016 business, technology, society (12th ed.). England: Britis Library Cataloguint-in

Laudon, K. C., Laudon, J. P., \& Elragal, A. (2015). Management Information Systems. England: Person Education LTD.

Lesmana, R., Sunardi, N., Hastono, H., \& Widodo, A. S. (2021). Perceived Quality Membentuk Customer Loyalty via Brand Equity pada Pengguna Smartphone Merek Xiaomi di Tangerang Selatan. Jurnal Pemasaran Kompetitif, 4(2), 157-167

Lesmana, R., Sutarman, A., \& Sunardi, N. Building A Customer Loyalty Through Service Quality Mediated by Customer Satisfaction.

Mangkunegara, Anwar Prabu. (2013). Manajmen Sumber Daya Manusia Peusahaan. Bandung: PT. Remaja Rosdakarya 
Mauliana, Parida (2012). Analisis Faktor-faktor yang mempengaruhi Volume Penjualan produk pada Minimarket Colour's Mart Pekan Baru. Skripsi. Pekan Baru : Universitas Islam Negeri Sultan Syarif Kasim Riau

Rangkuti, Freddy. (2014). Strategi Promosi Yang Kreatif. Jakarta : Gramedia Pustaka Utama

Rodhitullah, S.(2015). Pengantar Manajemen. Jakarta : Prestasi Pustaka Jakarta

Sa'ad, Walia Nabila (2017). Pengaruh E-Commerce terhadap Peningkatan Pendapatan Sentra Industri Keripik Pisang Bandar Lampung ditinjau dari Etika Bisnis Islam (Studi pada Sentra Industri Keripik Pisang di Kota Bandar Lampung).Skripsi. Lampung : Universitas Islam Negeri (UIN) Raden Intan Lampung

Santoso, Teguh (2011). Marketing Strategy. Yogyakarta : Oryza

Sari, Diyah Chandra Kartika dan Setya Chendra Wibawa. (2017). Pengaruh Penggunaan E-Commerce dalam proses penjualan terhadap minat berwirausaha siswa SMK Negeri Ngraho. Jurnal IT-EDU, Vol. 2, No. 1, tahun 2017, hal 16-23. Jurnal. Surabaya : Universitas Negeri Surabaya

Sarwono, Jonathan (2012). Metode Penelitian Kuantitatif dan kualitatif. Yogyakarta : Graha IImu

Setyawan, I Gusti Ngurah, I Wayan Sukadana, Made Detriasmita Saientisna. (2017). Pengaruh E-Commerce terhadap Penjualan Usaha pada Industri Pakaiana Jadi di Provinsi Bali. E-Journal Ekonomi Pembangunan Universitas Udayana, No. ISSN 2303-0178, Vol. 6, No. 12, Edisi Desember 2017 hal 2436-2461. Jurnal. Bali : Universitas Udayana

Siregar, Ir. Syofian. (2017). Metode Penelitian Kuantitif. Jakarta : PT. Fajar Interpratama Mandiri

Stanton,William J.(2012). Prinsip pemasaran, alih bahasa : Yohanes Lamarto. Jakarta : Erlangga

Sucahyo, Febriawan Adi. (2014). Analisis Harga dan Promosi terhadap Volume Penjualan pada Toko Olahraga Sport Smart FIK UNY. Skripsi. Yogyakarta : Universitas Negeri Yogyakarta.

Sudaryono.(2016).Manajemen Pemasaran Teori Dan Implementasi. Yogyakarta : ANDI

Sudjana , Nana. (2016). Penilaian Hasil Proses Belajar Mengajar. Bandung: PT Remaja Rosdakarya.

Sugiyono , (2012). Metodologi Penelitian Kuantitatif, Kualitatif, dan R\&D. Bandung: CV Alfabeta

Sujarweni, V. Wiratna (2014). Metode Penelitian : Lengkap, Praktis dan Mudah Dipahami. Yogyakarta : Pustaka Baru Press 
Sunardi, N., \& Lesmana, R. (2020). Konsep Icepower (Wiramadu) sebagai Solusi Wirausaha menuju Desa Sejahtra Mandiri (DMS) pada Masa Pandemi Covid19. JIMF (Jurnal IImiah Manajemen Forkamma), 4(1).

Supangat, Andi. (2010). Statistik dalam kajian deskriptif, Inferensi dan non parametrik. Jakarta : Kencana Prenada Media Group

Suparni, Niniek. (2009). Cyberspace Problematika Dan Antisipasi Pengaturannya. Jakarta : Sinar Grafika

Sutisna dan Pawitra. (2001). Perilaku Konsumen dan Komunikasi Pemasaran.Jakarta. PT. Remaja Rosdakarya

Swastha, Basu dan Irawan. (2010). Manajemen Pemasaran Modern. Yogyakarta: Liberty

Swastha, Basu, DH, dan Irawan. (2014). Manajemen Pemasaran.Yogyakarta: Liberty

Tanjung, Iwan Faisyal (2018). Analisa Manajemen Pemasaran dalam mengembangkan Usaha Seni Kaligrafi. Skripsi. Semarang : Universitas Islam Negeri Walisongo

Tjiptono, Fandy. (2015). Brand Management \& Strategy. Yogyakarta : Andi

Turban, E., et all. (2015). Electronic Commerce: A Managerial and Social Networks Perspective. 8 th Edition. New Jersey: Pearson Prentice Hall, inc.

Wibowo. (2017). Manajemen Kinerja. Jakarta: PT. Raja Grafindo Perkasa

Yulitasari, Deavy (2014). Pengaruh Biaya Promosi terhadap Volume Penjualan pada Yamaha Sudirman Motor Temanggung. Skripsi. Yogyakarta : Universitas Negeri Yogyakarta 